\title{
Integrated strategic model for managing regional projects in the field of ecology
}

\author{
Yuri Shedko ${ }^{1,}{ }^{*}$, Nadezhda Alenteva ${ }^{2}$, Sergey Anokhin ${ }^{3}$, Marina Lukiyanova ${ }^{1}$, and Vladimir \\ Starovoitov ${ }^{1}$ \\ ${ }^{1}$ Financial University under the Government of the Russian Federation, 49, Leningradskiy prospekt, \\ 125993, Moscow, Russia \\ ${ }^{2}$ Institution of International Law and Economics named after A.S. Griboedov, 21, Entuziastov shosse, \\ 111024, Moscow, Russia \\ ${ }^{3}$ Moscow Aviation Institute (National Research University), 4, Volokolamskoe shosse, 125993, \\ Moscow, Russia
}

\begin{abstract}
The article is devoted to review of authors' model of project management while executing the strategy of sustainable regional development. The article analyses the essence of social partnership as a collaborative instrument between government, business and society, which influences on economic progress nowadays. It is concluded that improvement of relations between actors of cooperation depends on institutional framework formation as well as on effective methods of management. In this paper there is defined such a condition of economic development as technological progress, which results in resources accumulation in developed regions but intensifies the problem of regional socio-economic inequality. There is proposed and proved the model of cooperation between society and government during implementation the strategy of regional development taking into account the digitalization. Thus resistance of the strategy depends on dimension of project agreement. In this context it becomes important to include into the strategy such a factor as trust. It should be noted that in the article there are defined organization opportunities, which have to be applied during strategic planning of the project to secure sustainable competitive position of the region and business entities. There are also described the reasons for resisting of project management adoption.
\end{abstract}

\section{Introduction}

Social partnership, securing the balance of interests of different society groups, corresponds to efficient mean of formation and implementation the strategy of sustainable regional development (i.e. federal subject and municipal settlement). Business participates in the social partnership, realized for the benefit of regional development, using such instruments as public private partnership, connected with cooperation between public and private sectors, and corporate social responsibility, expected to proceed voluntary deposit into society development, including social, economic and ecological spheres. In this respect

\footnotetext{
*Corresponding author: ynshedko@fa.ru
} 
convergence of interests and complementary activities of different regional actors are represented in strategic social alliance, i.e. chain regional organization. Using strategic model, including the methods of project management, and the concept "trust" allow to speed social and economic advancement as well as to protect positive environment for the purpose of increasing economic steadiness at macroeconomic level and encouraging technological breakthrough applying advanced digital. The proposed model can be recommended to be used in federal subjects and municipal settlement.

Tripartite partnership between government, business and society, realized by applying potential and resources of all participants, is considered to be an effective instrument of regional development. However the scientific challenge of cooperation between government, business and society is not clearly understood.

\section{Materials and methods}

The main direction of social and economic development in the regions of the Russian Federation at the process of cooperation between different actors refers to defining values, improving institutional and legal framework taking into account uneven growth. Hence all cooperation participants fulfill significant functions as follows: the state forms regulatory environment and defines the directions of regional development, society formulates social and economic problems, and business structures execute the order. Nowadays all structures of civil society influence on social and economic development, while extent of consolidation defines efficiency of implementation consequent strategy. In that context joining efforts means active participation of all participation sectors.

Statistics indicate socio-economic inequality among regions, and for depressive regions it becomes more difficult to get up with developed regions. Occurrence of territorial differentiation calls for solving such problems as development of fuel energy production, road transport, and food economy applying growth provision and increasing efficiency of the real economic strength. Consequently in each region it necessary to approve the set of instruments for the purposes of economic sectors development and infrastructure establishment considering the requirements of digital economy. It is necessary to add that the sphere of social and economic development includes such national interests as increasing the social stability, developing institutes of democracy, rationalizing cooperation between government and civil society, improving the quality of life (according to the Russian Federation Presidential Decree dated December 31, 2015 No. 683 "Concerning the Strategy of national security of the Russian Federation") (http://www.consultant.ru/document/cons_doc_LAW_191669/68b84fad7ba19e8382998868 34d575d4b0348533/).

From this perspective social and economic regional development depends on solving the main individual problems of each region. That is why in the purposes of the balanced sustainable development it is necessary to consolidate the potential of the participants, which secures synergetic effect and elimination of development disproportion. Nowadays the sphere of social and economic growth includes competitive recovery of national economy, which maintains defining target figures for the government taking into account consideration of business and society. Thus the strategy of social partnership can influence on improvement social and economic conditions, including growth in prosperity, availability of quality of services in different spheres. However theoretical and methodological procedures of cooperation between different structures come over the stage of formation. Therefore it is important to define the consequent growth vectors, which become the basis for realization the projects, and to create the mechanisms regarding contemporary recognition of negative external factors and methods of their elimination. In this context it should be pointed out that the elements of responsibility are the actual 
problems and methods of their solving, which form the basis for civil operations, expressed in social initiative. A significant role in the tripartite model of cooperation belongs to public organizations, which are ready to solve complex social problems. For these reasons it is necessary to construct the social dialogue between state and public sectors, which maintains setting the basis for cooperation development.

Thus the basis of the generated strategy model of cooperation between society and city form of government is considered to be such a feature of human capital as trust. There are suggested the elements of public management at local level, their consolidation and influence of the resulting effect of local authority. The elements/categories of the model were received by the method of benchmarking assessment and identifying the differences in the systems of municipal government at the process of strategic development.

Table 1. Model of integrated strategy (*Source: prepared based on the results of research Lukiyanova M., 2018).

\begin{tabular}{|l|l|l|}
\hline $\begin{array}{c}\text { Element/category of the } \\
\text { strategy }\end{array}$ & \multicolumn{1}{|c|}{ Content } & \multicolumn{1}{|c|}{ Correlations } \\
\hline Trust & $\begin{array}{l}\text { Confidence in the local } \\
\text { authorities }\end{array}$ & $\begin{array}{l}\text { 1: Popular reporting influences } \\
\text { on trust } \\
7: \text { Trust influences on public } \\
\text { engagement }\end{array}$ \\
\hline Popular reporting & $\begin{array}{l}\text { Public integrity, disclosure of } \\
\text { information concerning budget } \\
\text { expenses and activities, plans } \\
\text { and growth prospects }\end{array}$ & $\begin{array}{l}\text { 2: Public engagement } \\
\text { influences on trust }\end{array}$ \\
\hline Public engagement & $\begin{array}{l}\text { Participation of local } \\
\text { communities in the activity of } \\
\text { decision-making regarding } \\
\text { strategic and investment nature }\end{array}$ & $\begin{array}{l}\text { 3: Public works influence on } \\
\text { trust }\end{array}$ \\
\hline Public works & $\begin{array}{l}\text { Community relief focused on } \\
\text { realization of a common good } \\
\text { without expectation to gain } \\
\text { profit }\end{array}$ & $\begin{array}{l}\text { 5: Trust influences on public } \\
\text { works }\end{array}$ \\
\hline Results & $\begin{array}{l}\text { Results of activity of local } \\
\text { authority, expressed in social } \\
\text { effect, increase in business } \\
\text { activity, and tax power of the } \\
\text { regions }\end{array}$ & $\begin{array}{l}\text { 4: Public works influence on } \\
\text { results } \\
\text { 6: Trust influences on result }\end{array}$ \\
\hline
\end{tabular}

Therefore there are suggested the interconnections between the model elements as follows: popular reporting, public engagement, public works. The indicated elements increase trust to local authority, which leads to improvement of results of local authorities, expressed in receiving social effect, growth of business activity, and tax power of the regions. In exchange increase of trust leads to public engagement (management, decision making) and participation in social activity, i.e. there is a correction retraction. Moreover public works influence on social and economic development of the regions.

\section{Research Methods}

Monographic, economic, social and statistic methods were used to conduct the study. Empirical basis of the research was the conducted online enquiry of 31 participants aged 20 to 65 years. List of questions was formulated on the basis of the proposed model, focused on the system of assumptions regarding interconnections between elements of strategic process for municipal district. Working hypotheses and their indicators (questions) are 
represented in the table 2 .

Table 2. Working hypotheses and their indicators.

\begin{tabular}{|c|c|}
\hline Working hypotheses & Quality indicators \\
\hline 1: Popular reporting $\rightarrow$ Trust & $\begin{array}{l}\text { Indicated measures lead to public confidence in the } \\
\text { government: } \\
\text { Sheets with information disclosure regarding spending budget } \\
\text { funds } \\
\text { Information disclosure regarding activity (who, what, where, } \\
\text { explanatory work) }\end{array}$ \\
\hline 2: Public engagement $\rightarrow$ Trust & $\begin{array}{l}\text { Indicated measures lead to public confidence in the } \\
\text { government: } \\
\text { Survey questionnaire } \\
\text { Televised appearance and telephone calls during the } \\
\text { appearance } \\
\text { Official meeting on equal terms } \\
\text { Public deputy session } \\
\text { Press material } \\
\text { Telephone hot line }\end{array}$ \\
\hline 3: Public works $\rightarrow$ Trust & $\begin{array}{l}\text { Indicated measures lead to public confidence in the } \\
\text { government: } \\
\text { Popular participation on charity events } \\
\text { Popular participation in public works }\end{array}$ \\
\hline 4: Public & $\begin{array}{l}\text { Public works and charity events lead to: } \\
\text { Improvement of the population quality of life (quality of } \\
\text { urban environment) } \\
\text { Increase in business activity } \\
\text { Increase of tax revenues for the treasury }\end{array}$ \\
\hline 5: Trust $\rightarrow$ Publ & $\begin{array}{l}\text { Public confidence in the government leads to participation in } \\
\text { charity events and public works }\end{array}$ \\
\hline 6: Trust $\rightarrow$ Result & $\begin{array}{l}\text { Public confidence in the government lead to: } \\
\text { Improvement of the population quality of life (quality of } \\
\text { urban environment) } \\
\text { Increase in business activity } \\
\text { Increase of tax revenues for the treasury }\end{array}$ \\
\hline 7: Trust $\rightarrow$ Public engagement & $\begin{array}{l}\text { Public confidence in the government leads to public } \\
\text { engagement to local governance }\end{array}$ \\
\hline
\end{tabular}

For the purpose to analyze the opinion poll findings there were used nonparametric methods of mathematical statistics: for checking opinion consistency - concord coefficient of Kendall, for identifying the most significant activities - classification of ranks, for verification of hypotheses regarding acceptance of respondents with statement in the survey - criteria of Wilcoxon.

\section{Results}

The answers of the respondents "absolutely disagreed", "disagreed", "rather agree", "agree", "absolutely agree" signify the extent of acceptance with the statements of the survey, which are replaced by ordered categorical variables. Baseline information refers to the answers on the questions, evaluated according to five-grade scale of Likert, i.e. is not considered to be a quantitative index. Thus there were used nonparametric methods of mathematical statistics. 
It is concluded that the respondents likely agree with the proposed statement in the survey, i.e. mainly the answers were "rather agree", "agree", "absolutely agree". This conclusion is made on the basis of check for each statement of statistic hypothesis and the answers of the respondents in average correspond to the rate 3 or more according to the scale of Likert. One-sample test of Wicoxon is used for checking the hypothesis.

Calculation of mean value of the respondents showed that mean value was three or more for all statements except for "press material" (2.87), and "Increase of tax revenues for the treasury" (2.9). In this context for these two cases the alternative hypothesis is H1: $\mu<3$, and for others H1: $\mu>3$. The null hypothesis for all statements is the same : H0: $\mu=3$.

In the table 3 there are represented the calculated the values of the Wilcoxon criteria S+ for each statement, and their critical values for the left side critical area (the symbol* means the critical value for the left side critical area). On the basis of comparison of two indicators it is concluded that the hypotheses were accepted. The calculations were conducted taking into account the level of significance 0.05 .

Table 3. Results of the hypotheses check.

\begin{tabular}{|c|c|c|c|c|c|}
\hline 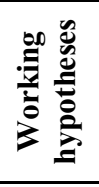 & Question of the survey & $\begin{array}{c}\text { Criteria } \\
\text { of } \\
\text { Wilcoxon, } \\
\mathbf{S}^{+}\end{array}$ & $\begin{array}{c}\text { Critical } \\
\text { value }\end{array}$ & $\begin{array}{c}\text { Conclusion } \\
\text { regarding } \\
\text { hypothesis } \\
\text { acceptance } \\
\mathbf{H}_{0} \\
\end{array}$ & $\begin{array}{c}\text { Check } \\
\text { (Answers of } \\
\text { the } \\
\text { respondent } \\
\text { s, average, }\end{array}$ \\
\hline \multirow[t]{2}{*}{ WH1 } & $\begin{array}{l}\text { Disclosure of information } \\
\text { regarding appropriate budget } \\
\text { expenditures }\end{array}$ & 252 & 192 & denied & more 3 \\
\hline & $\begin{array}{l}\text { Disclosure of information } \\
\text { regarding current activity }\end{array}$ & 352.5 & 257 & denied & more 3 \\
\hline \multirow{6}{*}{ WH2 } & Sociological survey & 52.5 & 79 & $\underline{\text { accepted }}$ & equal 3 \\
\hline & Meeting in video format & 72 & 100 & accepted & equal 3 \\
\hline & $\begin{array}{l}\text { Official meetings on equal } \\
\text { terms, discussions }\end{array}$ & 142.5 & 136 & denied & more 3 \\
\hline & Public legislature sessions & 271.5 & 208 & denied & more 3 \\
\hline & Press material & 86.5 & $61 *$ & accepted & equal 3 \\
\hline & Telephone line & 165 & 149 & denied & more 3 \\
\hline \multirow{2}{*}{ WH3 } & $\begin{array}{l}\text { Public participation in charity } \\
\text { events }\end{array}$ & 240 & 208 & denied & more 3 \\
\hline & $\begin{array}{l}\text { Participation in public } \\
\text { activities }\end{array}$ & 99 & 123 & $\underline{\text { accepted }}$ & equal 3 \\
\hline \multirow{3}{*}{ WH4 } & $\begin{array}{l}\text { Improvement of the quality of } \\
\text { life and urban environment }\end{array}$ & 296.5 & 224 & denied & more 3 \\
\hline & Increase of business activity & 240 & 192 & denied & more 3 \\
\hline & $\begin{array}{l}\text { Increase of tax revenues for } \\
\text { the treasury }\end{array}$ & 154 & 177 & $\underline{\text { accepted }}$ & equal 3 \\
\hline WH5 & $\begin{array}{l}\text { Public confidence in the } \\
\text { government leads to public } \\
\text { participation in charity events } \\
\text { and public works }\end{array}$ & 63 & 79 & accepted & equal 3 \\
\hline \multirow{2}{*}{ WH6 } & $\begin{array}{l}\text { Improvement of the quality of } \\
\text { life and urban environment }\end{array}$ & 167.5 & 136 & denied & more 3 \\
\hline & Increase of business activity & 131 & 163 & accepted & equal 3 \\
\hline
\end{tabular}




\begin{tabular}{|c|l|c|c|c|c|}
\hline & $\begin{array}{l}\text { Increase of tax revenues for } \\
\text { the treasury }\end{array}$ & 132 & $92 *$ & accepted & equal 3 \\
\hline WH7 & $\begin{array}{l}\text { Public confidence in the } \\
\text { government leads to public } \\
\text { engagement in local } \\
\text { government }\end{array}$ & 183.5 & 136 & denied & more 3 \\
\hline
\end{tabular}

Thus there is explored integrated strategy of regional projects management. On the basis of the results of calculations it is possible to make a conclusion as follows: the respondents answered on the questions positively, since the answers according to Likert scale correspond to the rank 3 or more. It confirms sustainability of the development strategy in terms of conformance, and supports validity of choosing the working hypotheses and their measures.

\subsection{Applying the integrated strategy in regional projects management}

Change of gross domestic product during five years (annual increase less $2.5 \%$ ) allows to define the economic forecast as inertial: current growth rate of economics, annual average growth rate of gross domestic product less $4-5 \%$, no availability of progressive structure changes in economics. It means that as the result of external factors effects there are not proceeded consequent measures, focused on reducing impact. However growth of gross domestic product in the country can be enhanced owing to implementation of new technologies, which are formed by general business efforts. At the moment therefore it is necessary to form the model of social partnerships between economic operators for the purpose of increasing the synergetic effect, leading to innovation development of different economic branches. Moreover efficiency of economic operators depends on such a factor as decrease of a social risk. In this case economic operators consolidate their efforts for the purposes of solving the questions as follows: social responsibility, coordination of economic interests, cooperation in different economic branches, achievement of long-term goals of social and economic development. Thus instrument of social partnership in the form of social project management among other methods can secure growth of national economics and eliminate possible institutional restrictions, i.e. brakes in reproduction process.

Strategic projects management is a complex approach towards achievement of sustainable competitiveness, gained in the process of co-ordination strategic business goals and projects management strategy.

Strategic management of projects is significantly important method for combining strategic and operational management, since it defines the processes, by which the company adapts to shifts. Realization of the strategy follows after accepting organization policies and practices, which correspond with the corporate strategy. Moreover exploration of the strategy includes the following parameters:

Defining organizational structures, processes and relations for the purposes of goals achievement in business;

Obtaining success owing to domination in such spheres as manpower resources, information technology, finances etc.

Besides it should be noted that while analyzing the projects management the main risk areas are staff listing, labor efficiency, bureaucracy, and organization reorganization.

Strategy realization is connected with the following elements: relations between projects management, knowledge management, and strategic project pipeline. Those entities, which organization structure corresponds with the strategy, better resist external forces and internal point of weakness, reaching better results. Consequently the decisions of the management regarding top concerns and capital expenditure should take into 
consideration the general conditions, including external and internal factors. Moreover on the one hand the projects correspond with organization structure and on the other hand the projects become a part of the company infrastructure. The strategy of the project relates independence of the project as well as its unique position as a part of a complex context.

Strategic projects management includes a group of practices, procedures, processes, instruments, and relations, which define the way how organizations get profit from cooperation between management of projects and business practices, focused on achieving general strategic goals. In this case the strategy represents a complex group of actions, oriented to using company resources for the purpose to achieve the target, which secures a sustainable a competitive position. Additionally strategic projects management includes projects management, directed at development of business skills and abilities, encouraging strength.

The current organization context and culture are characterized by quick changes, consequently the managers should adapt to shifts in terms of uncertainty.

Integrated strategic model of projects management allows reaching a sustainable competitive gain, providing the managers with strategies to achieve efficiency and monitor the situation, and the colleagues also recognize their contribution. Approach to projects management guarantees success with the required KPI (Key Performance Indicators) for cooperation with strategic concepts of realization such as a balances scorecard.

Actually this model is focused on development implicit knowledge in the company. Consequent stages, values, comprehension facilitate the process of training. This approach is supposed to delegate initiatives from the top management to the project team. In this way the group of monitoring and controlling process constantly examines quality achievement.

Development of the strategy can be studied as a process of making a decision regarding recognition of business essence and support of competitive advantage. In this regard it is necessary to highlight the reasons for rejecting the procedure of projects management:

Decentralization of power: projects management is intended to delegate powers regarding decision making, which plays down the impact of top managers;

Managers do not comprehend advantage of project management, since refer it to an operational level.

As soon as the company establishes the strategic basis it is necessary to plan strategic projects management.

Formulating the strategy includes the following conditions:

- Studying external environment and economic branch;

- Interpreting ecological changes for the purposes of possibilities and threats;

- Examining internal environment;

- Defining the main skills of the company and current business as well as strategy of corporate level;

- Achieving a sustainable competitive position by producing a mission and overview the company by analyzing strengths and weaknesses regarding ecological possibilities and threats;

Setting a goal for the purposes to realize the mission taking into account opportunity and result in the previous periods. Top management faces the necessity to make effective strategic investment decisions. Many processes of accepting strategic decisions concerning innovation were successful while defining and choosing strategic projects $[1,4]$.

Strategic planning of projects management includes definite stages as follows: goal setting, analysis, development of strategy, realization of strategy and monitoring, valuation and control.

Goal setting. The purpose of this stage is to define business vision. Goal setting includes determination the following key aspects:

- Setting short-term and long-term goals 
- Defining the process of goal setting

- Adapting the process among the colleagues and allocation of responsibilities

- Preparing the mission with the goals

- Correlating the strategy with possibility of goal achievement, and company values.

The stage of analysis includes systematic studying and assessment of the data, its groups for the purposes of finding the relations and defining cause and effect connections, which influence on the strategy, securing the basis for solving the problems and making decisions. This stage is a key one, since the data, collected in this stage, will form the following two stages. Moreover in the centre of the analysis there is a necessity to recognize the business needs for achievement a sustainable competitive advantage. Analysis allows setting a strategic direction and defining strategic initiatives, which can become a basis for development. It is also important to find out external and internal problems which can create a negative influence on goals achievement.

Development of strategy. The first stage if strategy development is analysis of information for the purposes to define the real resources, and those ones which can assist in achievement the definite goals. Then top management defines possibilities for obtaining extra input. At the same time it is necessary to examine arising problems and evaluate their influence on the corporate strategy. Thus step out analysis allows to define different scenarios.

Realization of strategy. On the one hand an effective realization of the strategy is a key to success for any business. On the other hand realization of the strategy is a stage of strategic management process. Moreover it can be necessary to make changes in that case of the general strategy does not correspond with the current business structure, which demands a new structure. Colleagues should comprehend their duties, and their contribution into general goal achievement.

The final stage in strategic planning is monitoring, valuation, and control, which include development of KPI, change of efficiency, and benchmarking assessment for the purpose to define if the strategy corresponds with the company goals. The main activities in this stage are as follows:

- Setting the base line for external and internal factors in the current strategy;

- Conducting productiveness;

- Making corrective actions.

In that case if the indicated activities were not successful, the process of strategic management should be repeated.

\section{Discussion}

A number of studies [2] validate the model of organization design, planning sustainable project management and development: «Based on the literature review results, we propose a new conceptual framework linking five key dimensions of sustainable project management: corporate policies and practices, resource management, life cycle orientation, stakeholders' engagement, and organizational learning». These studies can be characterized as divergent, since while solving practical tasks they do not answer the question regarding creating complex entire system of sustainable regional development. We propose that convergence is necessary, i.e. combination of the project management components in the terms of specified criteria.

Complication connected with choosing the project pipeline DEG refers to uncertainty in the area of making decision, correlation between projects and necessary coordination with strategic business goals. However these problems were not observed simultaneously [15]. The proposed methodology concerns the strategy approach regarding solving the problem 
of sustainable development of the region, which is beyond the range of projects management, i.e. external environment of the organization.

The researchers remark that the projects can be valuable for the participants in terms of development social skills, actual in digital era. Thus primary and subsequent socialization have a significant meaning. Particularly it is important for the colleagues at distance working to communicate during the life cycle of the project [7]. Resocialization means support of subsequent acquisition of norms, relations, necessary for participation in the organization. We approve this approach, and in the proposed model there are included the consequent stages of the project, which for the cycle of the project.

Researchers also note preconditions of creation and applying the practice of electronic government with project methods of management, which constructs multilevel structure of bureaucracy (government) and focus on management of project pipeline (i.e. complex project consisting of other projects), implements it in vertical of power using digital communication systems (i.e. platform). In methodology terms there is developed structural-functional matrix approach. The study constructs a multi-level governance structure with three main functions and applies this in an empirical setting. The results also describe how different governance practices and processes, focusing on project portfolio management, are applied vertically across different organizational levels to connect the ICT projects with the national digitalization strategy.

Proposed in this paper model of cooperation between the participants of the project allows to define the extent of opinion consistency, correspondence of strategic interests with internal values and goals of each participant. Unavailability of possibility to participate in management except for top managers means that for the purposes of sustainable project activity in the region it is necessary to develop three types of cooperation, i.e. engagement to strategic decisions, information disclosure of government authority, realization of public works in the region. On the basis of this approach there is developed the framework of making and executing decisions integration, and calculated the criteria of making decisions on the basis of consistency between the participants of cooperation. In this context there is involved motivation, creative, and intellectual capital as a part of general human potential in the region.

Researchers also point out that regional differences in expenses per information and communication technologies lead to divergence of innovation digital development in the regions [4]. However we state that information disclosure; including using digital technology, provide social and economic effects and consequences. The proposed model opens possibilities to set project procedures on digital platform. It is also important to underline a positive recognition of digital technologies significance as well as preparation of measures to stimulate its development [14].

Agaeva determines exploitation of digital systems of planning, realizing, and monitoring, which are used during projects management at federal and regional level [1], focused on identifying the system of projects management in the region in terms of digital economy, and proposes such a decision as forming a new executing structure in the form of a project office. The proposed methodology of sustainable development in the system of strategic management underlines the necessity to coordinate the projects (as strategic directions) before their realization for the purpose of integration (cooperation) of the participants, responsible for making and executing decisions. In this case the fundamental role of variance analysis decreases in the process of applying quantitative methods (in the form of such a traditional function as control check) on the basis of digital systems of planning and monitoring. We suppose that task solution concerns not only forming the organization structure (project office) but also including the stage of planning into the process of making decision, in particular according to group review, while participant take part in project execution. Moreover researchers also propose to create a multilevel system 
of vertical projects management in the terms of economy digitalization $[8,12]$.

In general the results of our work correspond with a new model of projects management and reflects recognition of achievements regarding the concept of cooperative business relations, i.e. partnership [5]. Researchers underline uncertainty regarding appropriate strategy for development, integration, and support of cooperation, particularly concerning practice of sustainable management in the infrastructure projects [6]. However our model allows to decrease this uncertainty without taking into account financial and economic effect [9], but focusing on processes and procedures.

\section{Conclusion}

Integrated strategy of projects management is considered to be a methodological basis for forming and developing the principles of the Public Government in the region, formed by local authority. The results of conducted research suggest that the management model, focused on public confidence in the government can change the attitude towards governmental and local authorities, being a part of bureaucracy. Thus the projects become the instruments, used for realization of development strategy. Strategies can be divided into tactics, which can be realized in the programs. Consequently the projects are supposed to refer to a definite strategic program, that is why it is necessary to observe the projects till the moment of achievement the goals using digitalization methods. Integrated model of strategic projects management can be effective during implementation the approach of projects management and realization the strategy of sustainable regional development.

\section{References}

1. L.K. Agaeva, Lecture Notes in Networks and Systems 160, 3-9 (2021) DOI: 10.1007/978-3-030-60929-0_1

2. S. Armenia, R.M. Dangelico, F. Nonino, A. Pompei, Sustainability (Switzerland) 11(9), 2664 (2019) DOI: 10.3390/su11092664

3. V.A. Blaginin, E.L.Plisetsky, Y.N.Shedko, I.S. Kobersy, N.K. Vasilieva, International Journal of Applied Business and Economic Research 5(23), 463-473 (2017)

4. E. Chirkunova, V.Y. Anisimova, N.M. Tukavkin, Lecture Notes in Networks and Systems 133, 123-130 (2021) DOI: 10.1007/978-3-030-47458-4_15

5. E. Eliseeva, 19th International multidisciplinary scientific GEOconference SGEM 2019 4.1, 299-306 (Albena, Bulgaria, 2019)

6. L. Kostygova, 19th international multidisciplinary scientific geoconference SGEM 2019, Energy and Clean Technologies 4.1, 757-762 (2019)

7. I. Oshri, J. Kotlarsky, P. Leslie, The Journal of Strategic Information Systems 16(1), 25-49 (2007) https://doi.org/10.1016/j.jsis.2007.01.001

8. T.M. Lappi, K. Aaltonen, J. Kujala, Transforming Government: People, Process and Policy 13(2), 159-196 (2019) DOI: 10.1108/TG-11-2018-0068

9. H. Liu, S. Song, Y. Hu, Transportation Research Part A: Policy and Practice 142, $115-$ 128 (2020) DOI: 10.1016/j.tra.2020.10.010

10. M. N. Lukiyanova, I. A. Zayarnaya, M. A. Kadyrov, Public Policy and Administration 17(4), 586-599 (2018) DOI: https://doi.org/10.13165/VPA-18-17-4-07

11. L.V. Matraeva, N.A. Korolkova, O.V. Kaurova, A.N. Maloletko, O.E. Bashina, Studies in Systems, Decision and Control 316, 197-207 (2021) DOI: 10.1007/978-3-030$57831-2 \quad 21$ 
12. D.E. Morkovkin, E.V. Kolosova, M.I. Sadriddinov, N.S. Semkina, A.A. Gibadullin, IOP Conference Series: Earth and Environmental Science 507, 012023 (2020) doi:10.1088/1755-1315/507/1/012023

13. A.N. Solomati, 13th International Conference Management of Large-Scale System Development MLSD 20209247737 (2020) DOI: 10.1109/MLSD49919.2020.9247737

14. M.A. Yudina, Stand Living Russ. Reg. 1(207), 60-65 (2018) DOI: https://doi.org/10.24411/1999-9836-2018-10007

15. Wu Yunna, Xu Chuanbo, Ke Yiming, Li Xinying, Li Lingwenying, Applied Energy 236, 444-464 (2019) https://doi.org/10.1016/j.apenergy.2018.12.009 